\title{
The Demographic Implications of Esca- lating Welfare Payments in Australia
}

\author{
D r. A R. Benson \\ University of Melbourne (Retired)
}

\begin{abstract}
This paper addresses the steady increase in Australian welfare beneficiaries. From 1979 to 2006, working-age welfare recipients on full income support increased from 5.6 to 10 per cent of the population. From 1996 to 1999, children of welfare recipients were found to be five times more likely to be receiving welfare benefits and were producing four and a half times more children than independent families.
\end{abstract}

Keywords: "Social welfare" "Welfare Dependence" "Dysgenics"

In Australia there is a continuing increase in the prevalence of welfare dependence. The fiscal pressure from the increase in the welfare state has generally been greater than the increases in revenue through taxes, economic reform and growth. [1] The Business Council of Australia (2004) predicted that relatively fewer funds will be available for future welfare.[2] In 1999, visiting English economist Deepak Lal stated: "nationalization of welfare accelerated in the twentieth century and led to vast transfer states (pensions). The accompanying erosion of traditional morality in the West is manifest in various social pathologies, such as widespread marriage breakdown, high levels of illegitimacy and divorce, proliferation of single-parent families, soaring crime rates, and the perpetuation of an urban underclass.’[3]

Figure: 1: $\quad$ Percentage of Pensioners in Population

(Recipients of Pensions, Benefits, Payments and Allowances)

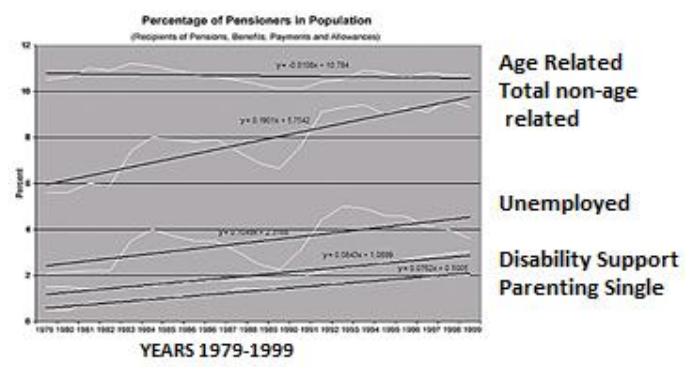

The above graph shows that all beneficiaries, except age pensioners, increased linearly in a population that increased from 14.6 million in 1979 to 19 million in 1999. It is noted that the recessions of 1982/83 and 1990/91 did not affect the trend-lines. Editions of the ABS publication Year Book Australia show that working-age welfare beneficiaries on full income support increased from $5.6 \%$ of the population in 1979 to $10 \%$ in 2006 , while age pensioners remained at $10 \%$. The increase in welfare prevalence was thus due to working age beneficiaries. After 1999, the figures are not strictly comparable, as there was increasing underemployment and more unemployed were transferred to the Disability Support Pension. The 2006 Year Book Australia shows continuing escalation of Disability Support from $3.05 \%$ of the popula- 
tion in 1999 to $3.47 \%$ in 2005 . In September 2004, unemployment was 5.5\%, underemployment $5.6 \%$ (4.5\% in 1980), and underutilization of the Extended Labour Force (unemployment, underemployment and a subset of persons marginally attached to the work force) $12.2 \%$.[4]

Review of a random selection of 53,000 Australian families from 1996 to 1999 by the Department of Family and Community Services Canberra showed that the apparent family size of welfare families was 3.1, non-welfare families 2.7 and the average of all families 2.9. Children from welfare families had four and a half times more pregnancies than those from non-welfare families. It was found that by age 19, those raised in welfare-dependent households were three times more likely than non-dependent families to become homeless, four times more likely to become teenage parents and five times more likely to end up on benefits.[5] Thus, the escalation of welfare payments is due to the greater apparent family size of welfare recipients (3.1) and whose children are five times more likely also to need support, over that of non-supported families (2.7).

Families are unable to cope independently for many different reasons: lack of innate ability, poverty, mental and physical illness, antisocial and criminal behavior. It can be shown that children are like their biological parents in all aspects of life. The most important example is intellect, where the correlation between IQ scores of parent (as child) and child is 0.56 , minus 0.01 between unrelated children reared apart (perfect correspondence is 1 , no correlation is 0 ). If differences in IQ were determined entirely by heredity, the expected value for parent and child is plus 0.50 , for children reared apart 0.00.[6] The behavior of all living organisms is the result of interaction between genetic inheritance and environment (nature and nurture). As children obtain their DNA from, and most are nurtured particularly in the early years by their biological parents, they resemble them in all aspects of life more than do unrelated people in the general population.

A joint project between the Federal Government, the ANU and the University of Melbourne is examining how disadvantage is transferred from one generation to the next. It is based on interviews with 4000 young people aged 18 and 3,900 parents and their Centrelink records. The project compares the life histories, attitudes and outcomes for young people whose parents have never received welfare payments with those who have received benefits. The payments include parenting payment, single disability support pension, and the Newstart allowance. It found young people from long-term, welfare dependent families did less well on every education and health measure and were more prone to risky behavior. In addition, young people's development of a work ethic and their attitude to welfare appeared to be shaped by their family's experience. Where families had been on welfare for at least six years, young people were almost three times as likely to have been suspended from school compared with young people with no family welfare history. About 20 per cent had a history of being late for school compared to less than 10 per cent of the more advantaged. They were less likely to be in classes for the gifted and talented and more likely to be in remedial classes. By age 18 , about 65 per cent of young people with no family welfare history were studying compared to about 40 per cent of the welfare group; and more than 30 per cent of those from fortunate backgrounds were at university compared with about 12 per cent of the disadvantaged group. Big differences were apparent in rates of depression and atten- 
tion deficit hyperactivity disorder and alcohol, tobacco and illicit drug use. To the researchers' surprise, almost 45 per cent of the less advantaged had asthma compared with 27 per cent of the better off.[7]

This paper addresses the increases in the three categories of working-age welfare beneficiaries and the accompanying social pathologies. There are many and varied individual reasons for welfare need and for being involved in social pathology, but the purpose of this paper is only concerned with the fact of their increase.

Poor health is a common cause of dependence and disadvantage. Many afflictions, including myocardial infarction, cerebral vascular pathology, osteoporosis and many cancers are increasing in prevalence. Because of modern medicine, many people with genetic diseases live long enough to reproduce and transmit their DNA to children: cystic fibrosis, hemophilia, diabetes, various heart defects, phenylketonuria, thalassemia and sickle cell anemia. The incidence of many of these disorders is rising in each generation.[8]

Certain behaviors and lifestyles cause significant ill health and social pathology, leading to disadvantage and dependence. The four diseases placing the greatest burden on the Australian population are ischemic heart disease, stroke, lung cancer and chronic airway disease. All four are smoking related.[9] Epidemiological studies have repeatedly demonstrated that drug abuse - mostly nicotine and alcohol - during the period leading up to fertilization and during pregnancy is a universal social problem; with countless potentially healthy children being needlessly handicapped.[10] Tobacco cigarette smoking kills half a million Americans each year and is the leading cause of preventable illness in the world today. Smoking harms nearly every organ in the body, compromising a smoker's general health and causing many diseases. This is because cigarette smoke contains thousands of chemicals, many of them toxic. The key ingredient underlying addiction to cigarettes is nicotine.[11] Genetic risk factors for nicotine dependence have been described,[12] and there is currently intense research for genes that may predispose people to undertake behaviors that have adverse physical and mental health effects.

The introduction of no-fault divorce laws, the single mother's pension in 1975 , and the de stigmatizing of illegitimacy have been associated with easier divorce, desertion and changes in community standards. In 1975, 18 per cent of women cohabited with a male partner before marriage; in 1992, 58 per cent. Five per cent of births occurred outside marriage in 1960, 27 per cent in 1996. Ninety-one per cent of teenage births in 1999 were extra- nuptial.[13]

Criminal behavior has escalated. The Source Book of Australian Criminal and Social Statistics reported that from every account it is clear that the reported rate of many crimes is growing at an accelerated pace. This publication reveals that over the period $1980 / 81$ to $1986 / 87$, homicide increased at a rate twice that of the population growth rate, rape and burglary five times.[14] The Australian prison population of 25,000 is two and a half times that of 20 years ago.[15]

As we have seen, young women whose parents had been welfare recipients are five times more likely also to be receiving welfare benefits, and produced four and a half times more children during 1996 to 1999 than independent families.[16] There were no significant welfare eligibility changes, and part of the reason for the increase in the need for welfare services is the excess apparent family size of welfare families (3.1) over that of families with medium to high income (2.7). 
Increasing dependence and the accompanying social pathologies is a very serious concern. In the United States, welfare numbers were reduced by 60 percent in 5 years through tax incentives, work place changes and time limits on benefits. In Australia, Peter Saunders (2004) outlined several measures that undoubtedly could reduce welfare numbers in Australia[17] in the short term, but these have not been enacted, and those who don't want to work, who are prepared to defraud the system, and disadvantaged families in genuine need of welfare will continue to escalate while they have a greater apparent family size than that of independent families.

The acceptance of Darwinian evolution and modern molecular genetics show that it is impossible to break the nexus between the natures of parents and children. The basics of Darwinism are heritable variation and natural selection - now generally accepted as fact rather than theory. There is no doubt that generation of genetic variation is an intrinsic property of sexually reproducing organisms, and no doubt that natural selection has historically censored unsuitable variation and maintained organisms in harmony with their environments. In a feral environment natural selection acts on the whole organism, and only allows successful survival and procreation in an environment similar to the one in which the organism evolved (a compatible environment).

All theories within psychology imply the existence of psychological mechanisms underlying behavior. Evolutionary psychology states: 'Behavior depends on a large number of underlying evolved, functionally specialized psychological mechanisms (information processing devices housed in the brain), each sensitive to the concept of a particular adaptive problem that has recurred for humans over evolutionary time.[18] Apprehen- sion of a concept/problem includes an emotion that gives power to supersede other current events, trigger a genetically determined program of behavior to solve it, bring it to consciousness and place it in memory. As every aspect of life has evolved, the genome determines developmental and behavioral responses to the environment from the fertilized egg to adulthood - but requires an historical environment similar to the one in which it evolved and developed for successful survival and procreation. Learning involves the apprehension and memorizing of events associated with the adaptive problems triggered. We thus learn to recognize circumstances in the real world that are associated with the triggered innate concepts - we learn how the world 'works,' but the response to how the world is perceived is innate. Neuroscience research using functional magnetic resonance imaging (fMRI) and positron emission tomography (PET) shows that brain activity initiating behavior occurs about three quarters of a second prior to conscious awareness of the intention to act. Thus actions are initiated by unconscious mechanisms that are, presumably, genetically hard-wired into the brain.[19]

Differences between individuals are due to a different genome and a different environment. Research in behavior genetics has shown that each contributes about $50 \%$ to human individual differences in most cognitive and personality traits.[20] As each genome evolved and developed to survive in a particular culture, it cannot survive and develop successfully in an incompatible one. Also, if any developmental or psychological mechanism is not triggered to activation at the appropriate time in early life, it will be lost. The human brain is only about $63 \%$ developed at birth and not fully developed until puberty, so an incompatible environment before that age re- 
sults in greater or lesser permanent harm. Attachment theory emphasizes that the embryo depends on its mother for nutrition and care from the time of conception, and if she is neglectful of her own health and not virtually constantly loving and caring in the developing ages up to puberty and certainly up until about six or eight years, permanent physical and psychological harm results.

Jacques Monod wrote in 1971: '... Selection in modern societies has been done away with - at least there is nothing "natural" about it in the Darwinian sense. To the extent that selection is still present, it does not favor the "survival of the fittest" - in modern terms, the genetic survival of the "fittest" through a more numerous progeny. Intelligence, courage, and imagination are still factors of success in modern societies; ...but of personal, not genetic success, the only kind that matters for evolution. The situation is the reverse: statistics, as everybody knows, show a negative correlation between the intelligence quotient (or cultural level) and the average number of children per couple. The same statistics demonstrate a high positive correlation of intelligence quotients between marital partners - a dangerous situation that could gradually edge the highest genetic material toward concentration of intelligence quotients within a shrinking elite.

Until not so long ago, even in relatively "advanced" countries, the weeding out of the physically and also mentally least fit was automatic and ruthless. Most of them did not reach the age of puberty. Today, many of these live long enough to reproduce. Thanks to the progress of scientific knowledge and the social ethic, the mechanism that used to protect the species from degeneration (the inevitable result when natural selection is suspended) now functions hardly at all, save where the defect is uncommonly grave. For coping with these dangers, there are occasional promises of remedies expected from the current advances in molecular genetics. ... No doubt it will be possible to palliate certain genetic flaws, but only in the afflicted individual, not in his posterity. Not only does modern molecular genetics give us no means whatever for acting upon the ancestral heritage in order to improve it with new features - to create a genetic "superman" - but it reveals the vanity of any such hope: the genome's microscopic proportions today and probably forever rule out manipulation of this sort. The only means for "improving" the human species would be to introduce a deliberate and severe selection. Conditions of non-selection (or selection in reverse) like those reigning in the advanced societies lead inevitably to species degeneration.'[21]

To most people, the thought of being in thrall to their genes is intolerable. Books and articles have recently been written on the ability of the environment to change the way the developing genome responds to the environment - the so-called "plasticity' of the brain/mind. Two recent books describe brain plasticity on the background of attachment theory, based almost exclusively on evidence from incompatible environments during development.[22] In other words, the genome does not change - but it does not develop and function normally in an incompatible environment. A further consequence of selection is that only some form of eugenics can stop the degeneration of an increasing proportion of the world's population.

Everything else being equal, the need for welfare will continue to increase for as long as welfare beneficiaries bear more children than independent families. Procreating while significantly disadvantaged underlies most of the world problems of increasing misery, starvation, 
poverty, antisocial and criminal behavior - where children are brought into the world by parents who, for any reason, lack the opportunities, characteristics, abilities and resources to cope with their environment. The provision of social, medical and legal help for those in genuine need is morally right, but the increasing social and economic costs are unsustainable.[23] [24]

If the reader will permit the author to conclude this article with some conclusions about how to benefit society, they would be as follows: A child surely has the right to be conceived and reared by competent parents, and not brought into an environment of dysfunctional dependence, poverty and a higher than average probability of ending up in the same state. Possible action through disincentives such as the generation of a public attitude against unlimited indigent procreation could be a practical way of achieving something worthwhile. The alternative of doing nothing is the persistent escalation of present adverse and unsustainable trends. For the sake of present and future generations, there is urgent need for informed discussion to resolve this serious long-term problem.

\section{POSTSCRIPT}

I believe this paper addresses Dysgenic Indigent Fertility as the ONLY cause of welfare and population escalation.

The present welfare institution should continue. An additional allowance should be offered to bring the total incomes of welfare beneficiaries and lowpaid workers to near that of the average population wage - providing they do NOT conceive a child while requiring such help.

\section{References}

[1] Warby, Michael (July 2000). Making welfare sustainable. The Institute of Public Affairs Review 2: 13.
[2] Business Council of Australia (2004). Aspire Australia 2025.

[3] Lal, Deepak (Febr. 1999). Renewing the Miracle. The Institute of Public

Affairs Review 1: 15.

Deepak Lal is now Coleman Professor of International Development

Studies at University of Los Angeles, emeritus professor political economy

University College London and a senior fellow at the Cato Institute

[4] ABS (Australian Bureau of Statistics, Canberra) (2000). Year Book Australia 2000. Catalogue No.1301. ISSN 1312-4746. Unless otherwise stated, all raw data are from ABS publications 'Year Book Australia' up to year 2006 and cover 1979 to 2005. Only full pensions and major categories of benefits were considered in the graphs. Age and Service (both with wives and carers), Disability Support (with wives and carers) and Widows' Pensions; Special Benefits, Sickness Benefits and Allowances; Parenting Payments (Single, Sole and Supporting Parent); and Unemployment Allowances (Unemployment, Newstart, Job Search, and Mature Age). All are paid as the main source of income (Age rate), all are subject to income and asset testing, and there were no significant changes to eligibility criteria over the reviewed period. Those receiving War Pensions, Workcover or Parenting (Partnered) Payments were not included

[5] Pech, Jocelyn \& McCoull, Francis (1999). Transgenerational Welfare Dependence; Myth or Reality? Research paper presented to the $1999 \mathrm{Na}$ tional Social Policy Conference, Sydney NSW: Social Policy for the 21st Century: Justice and Responsibility. SPRC reports and proceedings no.142. vol. 2, pp. 185-198, tables. Social Policy Research Centre, University of NSW. 1996-99 research on 
52,742 Australian families: Middle to high income families have a mean of 2.7 children, low income 3.3 , income support families 3.2 children. Australian

population fertility rate (TFR) $1.75-1.9$.

[6] Eysenck, Hans J. (1971). Race, Intel-

ligence and Education. , p. 62. Sun

Books ISBN 0725101261.

[7] Cobb-Clark, Deborah. Professor of

Economics, Australian National University. From an interview by Adele Horin published in The Age newspaper Oct. 1, 2009.

[8] Van Court, Marian. A review of Dysgenics: Genetic Deterioration in Modern

Populations by Richard Lynn, 1996, Journal of Social, Political and Economic Studies

23(2), Summer 1998. MVC.

Also an unabbreviated Internet version.

www.prometheism.net/articles/

dysgenics.html (downloaded 5 $1110)$

[9] Whiteman, David \& Hayward, Nick, (2001). Life Science 13(4), 38.

[10] Pollard, Irina \& Gilbert, Stephen, 1998. Love, Life and Children: A

Practical Introduction to Bioscience Ethics. University of Washington Press

[11] Volkow, Nora D. Director, National Institute of Drug Abuse (USA). http://137.187.56.161/about/welcome/Me ssagenicvax.html

[12] Kendler, Kenneth S., Thornton, Laura M. \& Pedersen, Nancy L. (2000).

Tobacco consumption in Swedish twins reared apart and reared together. Archives of General Psychiatry 57: 886892.

[13] ABS (Australian Bureau of Statistics, Canberra) (2000). Year Book

Australia 2000. Catalogue No.1301. IBSN 1312-4746.

[14] 15 Source Book of Australian

Criminal and Social Statistics 1894-

1988. Australian Institute of Criminology, Canberra A.C.T. IBSN 0

642 13569X.

[15] Emerson, Craig (Labour M.P.) (Oct. 5, 2006). Expanding Opportunity for the Welfare State. Address to the Centre for Independent Studies, Sydney
[16] Pech, Jocelyn \& McCoull, Francis, op. cit. (reference 5).

[17] Saunders, Peter (2004). Australia's Welfare Habit and How to Kick It. ISBN 186432092 3. Centre for Independent Studies, pp 4,101 and general chapters.

[18] Buss, David (2004). The Oxford Companion to the Mind, 2004 edition.

[19] Ramachandran, Vilayanur S. (2003). Reith Lectures, No. 5.

[20] Newsom, A. \& Williamson, Robert, 1999. Should We Undertake

Genetic Research in Intelligence? Bioethics 13(3/4), 328-330.

[21] Monod, Jacques, Nobel Laureate 1965 for elucidating the replication mechanism of genetic material and the manner in which cells synthesize protein. Chance and Necessity 1971 ISBN: 0-39446615-2.

[22] Ridley, Matt (2003). Nature via Nurture, ISBN 184115746 5. Dodge,

Norman (2010). The Brain that Changes Itself. 9781921372742.

[23] Business Council of Australia (2004). Aspire Australia 2025.

[24] ABS (Australian Bureau of Statistics, Canberra) (2000). Year Book 